\title{
Plant-Virus Interaction on Orchids Infected Odontoglossum ringspot virus (ORSV) in Bogor Botanical Garden, Indonesia
}

\author{
Mahfut $^{1}$, Budi Setiadi Daryono ${ }^{2}$, Ari Indrianto ${ }^{3}$, Soesamto Somowiyarjo ${ }^{4}$ \\ ${ }^{1}$ Department of Biology, Faculty of Mathematics and Natural Sciences, Universitas Lampung, \\ Indonesia. 35145 \\ ${ }^{23}$ Faculty of Biology, Universitas Gadjah Mada, Indonesia. 55281 \\ ${ }^{4}$ Department of Plant Disease, Faculty of Agriculture, Universitas Gadjah Mada, Indonesia. \\ 55281 \\ \{mahfut.mipa@fmipa.unila.ac.id², bs_daryono@mail.ugm.ac.id², ariindri@ugm.ac.id², \\ soesamto@faperta.ugm.ac.id $\left.{ }^{4}\right\}$
}

\begin{abstract}
Biotic stress by Odontoglossum ringspot virus (ORSV) infection causes a decrease in the rate of photosynthesis. This study aimed to determine the pattern of plant-virus interactions through analysis of rbcL and coat protein genes. Virus source was collected from Bogor Botanical Garden. Detection of chloroplast and ORSV using Reverse Transcriptase-Polymerase Chain Reaction (RT-PCR) and Polymerase Chain Reaction (PCR), respectively. Analyzed change of nucleotide and amino acid sequences using DNASTAR and MEGA Beta programs. Chloroplast DNA and virus RNA amplification managed to get amplicons at $\pm 599 \mathrm{bp}$ and $\pm 474 \mathrm{bp}$, respectively. Sequence nucleotides analysis showed point mutations with increased synthesis of Ser, Glu, Pro, dan Arg amino acids. This study revealed a change in sequence of nucleotides and amino acids were thought to be adaptations and physiological responses of host-virus to natural environments in Indonesia.
\end{abstract}

Keywords: ORSV, Chloroplast, Coat Protein Gene, rbcL, Plant-Virus Interaction, Bogor Botanical Garden, Indonesia.

\section{Introduction}

Orchid is the ornamental plant have the highest demand in the market. Infection of pests and disease is still a major obstacle in the attempt of cultivating orchids [6]. Viral infection is the most important limiting factor because it can lower the quality of the plants [12]. Orchids are reported to be infected by the more than 30 types of viruses [16]. One of the most widely reported virus infected by the spread in the world including Indomesia are Odontoglossum ringspot virus (ORSV) [14].

ORSV or also known as Tobbaco mosaic virus orchid strain (TMV-O) first reported infecting orchids in Indonesia since 1996 [3]. This virus belongs to the Genus Tobamovirus and Familia Virgaviridae. The structure particles of the rigid rod-shaped $300 \mathrm{~nm} \times 18 \mathrm{~nm}$, 
same as TMV. Composition nucleic acid of ORSV particle containing 2-5\% RNA and the viral protein sub-unit is 157 amino acid residues. Symptoms in the form of mosaic and chlorotic with a pattern of stripes or rings (ringspot) on the surface of the leaves, as well as the colour breaking on flower [4].

Information about orchid disease caused by ORSV infection in Indonesia is very limited. Research on the detection and characterization of ORSV in Indonesia has been reported $[6,7,8,9]$. Biotic stress affects issues declining ability of photosynthesis. This is due to the presence of chloroplasts damage followed by disruption of rubisco enzyme synthesis. Rubisco (ribulose-1,5-bisphosphate carboxylase) is the fixatition enzyme of $\mathrm{CO}^{2}$ generated by the $r b c L$ gene. According to [15], these enzymes function in the reaction RuBP carboxylation into 2 molecules of 3-PGA (fosfogliserat acid) in the Calvin cycle.

This research aims to study the host-virus interaction patterns as the process of plant adaptation to changes in the environment through the identification of coat protein genes ORSV and $r b c L$ gene. Similar studies have been carried out but in hybrid orchids. This research is the first study to plant-virus interaction on native orchids infected ORSV in Indonesia.

\section{Materials and Methods}

\subsection{Virus Source}

Samples were collected during May-June 2014 and April-May 2016 from Bogor Botanical Gardens, West Java. Orchid leaves positive samples infected ORSV are Phalaenopsis amabilis leaves with mosaic and chlorotic mixed symptoms, then referred to as KRB. As a comparison the respective of the Phalaenopsis amabilis leave the result of in vitro culture as negative control and the orchid Phalaenopsis amabilis leave positive infected ORSV as positive control.

\subsection{Molecular Detection of Coat Protein Gene}

RNA isolation on a sample positive infected ORSV based on ELISA, using a Total RNA isolation kit (SBS Genetech Co., Ltd., China). According to [7], amplification of RNA by RTPCR was performed with a separate method using specific primer, i.e. ORSV CP-F1 (5'ATGTCTTACACTATTACAGACCCG-3') and ORSV CP-R1 (5'GGAAGAGGTCCAAGTAAGTCC-3'). The process of RT using the first strand cDNA synthesis kit (Thermo scientific, USA), subsequently cDNA molecules that form is used as the mold in the process of PCR using GoTaq GreenMaster Mix (Promega, USA). RT reaction performed at temperature $37^{\circ} \mathrm{C}$ for 60 minutes, followed by incubation $96^{\circ} \mathrm{C}$ for 5 minutes and terminated at a temperature of $4^{\circ} \mathrm{C}$. Amplification of cDNA are begining with predenaturasi at $95^{\circ} \mathrm{C}$ for 5 minutes, followed by 34 cycle, including denaturation temperature $95^{\circ} \mathrm{C}$ for 30 seconds at a temperature of $50^{\circ} \mathrm{C}$, annealing for 45 seconds, and extension at a temperature of $70^{\circ} \mathrm{C}$ for 1 minute. PCR products were analyzed using electrophoresis on agarosa gel $2 \%$, in $1 \mathrm{x}$ TBE buffer previously soaked in ethidium bromide. DNA visualization on UV transluminator (Bio-Rad Transilluminator 2000). 


\subsection{Molecular Detection of $r b c L$ Gene}

Genomic DNA isolation done in accordance with the protocols of DNA isolation kit (Phytopure). According to [10], amplification of DNA by PCR (Polymerase Chain Reaction) using a pair of primary, i.e. rbcLa-F (5'-ATGTCACCACAAACAGAGACTAAAGC-3') and rbcLa-R (5'-GTAAAATCAAGTCCACCGCG-3'). The reaction is performed using a Thermocycler (Boeco) with PCR kit GoTaq GreenMaster Mix (Promega, USA). DNA amplification is started by predenaturasi phase at a temperature of $94^{\circ} \mathrm{C}$ for 3 minutes, followed by 34 cycle, includes the denaturation at temperature $94^{\circ} \mathrm{C}$ for 30 seconds, annealing at temperatures of $55^{\circ} \mathrm{C}$ for 30 seconds, and extensions at $72^{\circ} \mathrm{C}$ for 1 minute. After the cycle was completed, then followed post-elongation 10 minutes at a temperature of $70^{\circ} \mathrm{C}$ and cooling at a temperature of $4^{\circ} \mathrm{C}$. PCR products were analyzed using electrophoresis on agarosa gel $2 \%$. DNA visualization shows base pair length indicate the size of $r b c L$ gene.

\subsection{DNA Sequence Analysis}

Nucleotide sequence analysis is performed by sending a sample of the results of the amplification to $1^{\text {st }}$ Base company, Malaysia. The data is analyzed and combined using the Software Suite for Sequence Analysis DNASTAR Lasergene DM Version 3.0.25. Analysis of the parallel sequence performed with Molecular Evolutionary Genetics Analysis (MEGA).

\section{Results and Discussion}

\subsection{Molecular Detection of CP Gene ORSV and $r b c L$ Gene Chloroplasts}

Results of detection with PCR against control and positive samples ORSV showed fragments of DNA amplification sized \pm 474 bp dan \pm 599 bp which is $C P$ gene and $r b c L$ gene, as reported $[6,7,8,9,10]$.

\subsection{Sequence Analysis of $C P$ Gene ORSV}

Sequence analysis of $C P$ gene sequencing results obtained total nucleotide control and isolates each 480 bases. The percentage of isolates of both sequence homology is $99.97 \%$. $\mathrm{KRB}$ isolate has a percentage of GC base content higher than control i.e. $20.35 \%$ of average 20.3. While the percentage content of bases AT 29.65\% lower than the average of $29.7 \%$. Based on the analysis of the parallel sequence obtained the presence of point mutations in the form of a deletion, and substitution transition. On this research not found insertions. The effect of mutation are able to cause a change in the codon triplet encoder amino acid (Table 1). The percentage of amino acids that are translated on the controls and KRB isolates are 160 and 155 amino acids. Analysis of the frequency of amino acids showed isolates KRB has decreased amino acid Cys and Leu, as well as an increase in Ser and Glu (Table 2).

Table 1. Point mutations on $C P$ gene sequence and changes of amino acids on orchid infected ORSV isolate KRB

\begin{tabular}{llllllllllllllll}
\hline $\begin{array}{l}\text { The Type of } \\
\text { Mutation }\end{array}$ & \multicolumn{11}{c}{ Number of Sequence } \\
\hline Point mutation & G2 & T & C & T & A5 & G1 & T & C & T & T & G & A & C & A & T \\
sequence & 6C & 3 & 3 & 5 & $6 G$ & 43 & 1 & 2 & 2 & 3 & 4 & 4 & 4 & 4 & 4 \\
\hline
\end{tabular}




\begin{tabular}{|c|c|c|c|c|c|c|c|c|c|c|c|c|c|c|c|}
\hline \multirow{8}{*}{$\begin{array}{l}\text { Change of } \\
\text { amino acid }\end{array}$} & \multirow{8}{*}{$\begin{array}{c}\text { C9 } \\
\text { S }\end{array}$} & 0 & 6 & 5 & & \multirow[t]{3}{*}{$\mathrm{A}$} & 7 & 0 & 9 & 8 & 1 & 4 & 4 & 4 & 4 \\
\hline & & \multirow[t]{2}{*}{-} & \multirow[t]{2}{*}{$\mathrm{G}$} & \multirow{2}{*}{\multicolumn{2}{|c|}{-}} & & 6 & 0 & 3 & 9 & 9 & 0 & 1 & 2 & 4 \\
\hline & & & & & & & $\mathrm{G}$ & A & $\mathrm{C}$ & $\mathrm{C}$ & - & - & - & - & - \\
\hline & & $\mathrm{N}$ & - & $*$ & $* 19$ & $\mathrm{~S} 4$ & $\mathrm{~L}$ & A & $\mathrm{L}$ & I & $\mathrm{R}$ & $Y$ & $Y$ & $\mathrm{~T}$ & $\mathrm{~T}$ \\
\hline & & 1 & & 1 & - & $8 \mathrm{~N}$ & 5 & 6 & 9 & 1 & 1 & 1 & 1 & 1 & 1 \\
\hline & & 0 & & 9 & & & 9 & 7 & 8 & 3 & 4 & 4 & 4 & 4 & 4 \\
\hline & & - & & - & & & $\mathrm{R}$ & E & $\mathrm{S}$ & 0 & 0 & 7 & 7 & 8 & 8 \\
\hline & & & & & & & & & & $\mathrm{T}$ & - & - & - & - & - \\
\hline
\end{tabular}

Table 2. Frequency of amino acid $C P$ gene on control and orchid infected ORSV isolate KRB

\begin{tabular}{|c|c|c|c|c|c|c|c|c|c|c|c|c|c|c|c|c|c|c|c|c|c|}
\hline \multirow[t]{4}{*}{ Isolate } & \multicolumn{21}{|c|}{ Frequency of Amino Acid (\%) } \\
\hline & $\mathbf{A}$ & $\mathbf{C}$ & $\mathbf{A}$ & G & $\mathbf{P}$ & G & $\mathbf{H}$ & $\mathbf{I}$ & $\mathbf{L}$ & $\mathbf{L}$ & $\mathbf{M}$ & $\mathbf{A}$ & $\mathbf{P}$ & $\mathbf{G}$ & $\mathbf{A}$ & $\mathbf{S}$ & $\mathbf{T}$ & $\mathbf{V}$ & $\mathbf{T}$ & $\mathbf{T}$ & $\mathbf{T}$ \\
\hline & I & $\mathbf{y}$ & $\mathbf{s}$ & 1 & h & I & $\mathbf{i}$ & I & $\mathbf{y}$ & e & $\mathbf{e}$ & $\mathbf{s}$ & $\mathbf{r}$ & I & $\mathbf{r}$ & $\mathbf{e}$ & h & $\mathbf{a}$ & $\mathbf{r}$ & $\mathbf{y}$ & $\mathbf{0}$ \\
\hline & $\mathbf{a}$ & $\mathbf{s}$ & $\mathbf{p}$ & $\mathbf{u}$ & $\mathbf{e}$ & $\mathbf{y}$ & $\mathbf{s}$ & $\mathbf{e}$ & $\mathbf{s}$ & $\mathbf{u}$ & $\mathbf{t}$ & $\mathbf{n}$ & $\mathbf{o}$ & $\mathbf{n}$ & $\mathbf{g}$ & $\mathbf{r}$ & $\mathbf{r}$ & 1 & $\mathbf{p}$ & $\mathbf{r}$ & $\mathbf{t}$ \\
\hline \multirow[t]{4}{*}{ Control } & 2 & 0 & 1 & 4 & 4 & 4 & 2 & 8 & 3 & 1 & 6 & 2 , & 2 & 5 & 4 & 9 & 6 & 5 & 2 & 3 & 2 , \\
\hline & , & , & , & , & , & , & , & , & , & 8, & , & 7 & , & , & , & , & , & , & , & , & 0 \\
\hline & 0 & 6 & 3 & 1 & 8 & 8 & 0 & 9 & 4 & 6 & 2 & 6 & 7 & 5 & 8 & 6 & 2 & 5 & 0 & 4 & 7 \\
\hline & 7 & 9 & 8 & 4 & 3 & 3 & 7 & 7 & 5 & 2 & 1 & & 6 & 2 & 3 & 6 & 1 & 2 & 7 & 5 & \\
\hline \multirow[t]{4}{*}{ KRB } & 1 & 0 & 1 & 4 & 4 & 4 & 2 & 8 & 3 & 1 & 6 & 2 , & 2 & 5 & 4 & 1 & 6 & 5 & 2 & 2 & 1 , \\
\hline & , & , & , & , & , & , & , & , & , & 7 & 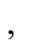 & 8 & 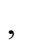 & , & , & 0 & , & , & , & , & 4 \\
\hline & 4 & 0 & 4 & 9 & 9 & 9 & 1 & 5 & 5 & 7 & 3 & 4 & 8 & 6 & 9 & 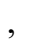 & 3 & 6 & 1 & 8 & 2 \\
\hline & 2 & 0 & 2 & 6 & 6 & 6 & 3 & 1 & 5 & 3 & 8 & & 4 & 7 & 6 & $\begin{array}{l}6 \\
4\end{array}$ & 8 & 7 & 3 & 4 & \\
\hline
\end{tabular}

\subsection{Sequence Analysis of $r b c L$ Gene Chloroplasts}

Sequence analysis of $r b c L$ gene sequencing results obtained total nucleotide control and isolates each 587 bases. The percentage of isolates of both sequence homology is $99 \%$. KRB isolate has a percentage of GC base content higher than control i.e. $20.7 \%$ of average $20.65 \%$. While the percentage content of bases AT $29.3 \%$ lower than the average of $29.35 \%$. Obtained the presence of point mutations in the form of a deletion, insertion, and substitution transition. The percentage of amino acids that are translated on the controls and KRB isolates are 201 amino acids (Table 3). Analysis of the frequency of amino acids showed isolates KRB has decreased amino acid Ser and Trp, respectively, as well as an increase in Pro and Arg (Table 4).

Table 3. Point mutations on $r b c L$ gene sequence and changes of amino acids on orchid infected ORSV isolate KRB

\begin{tabular}{|c|c|c|c|c|c|c|c|c|c|c|c|c|c|c|c|c|c|c|}
\hline The Type & \multicolumn{18}{|c|}{ Number of Sequence } \\
\hline Point & $\mathrm{T}$ & $\mathrm{G}$ & $\mathrm{C}$ & - & $\mathrm{T}$ & - & $\mathrm{T}$ & $\mathrm{C}$ & $\mathrm{C}$ & $\mathrm{T}$ & $\mathrm{T}$ & $\mathrm{A}$ & $\mathrm{T}$ & $\mathrm{A}$ & $\mathrm{T}$ & $\mathrm{G}$ & $\mathrm{T}$ & $\mathrm{C}$ \\
\hline mutation & 1 & 1 & 2 & 2 & 2 & 2 & 3 & 4 & 4 & 4 & 4 & 4 & 5 & 5 & 5 & 5 & 5 & 5 \\
\hline \multirow[t]{3}{*}{ sequence } & 6 & 6 & 5 & 5 & 6 & 6 & 1 & 1 & 2 & 2 & 5 & 6 & 0 & 4 & 7 & 7 & 7 & 7 \\
\hline & 6 & 9 & 6 & 8 & 6 & 7 & 4 & 3 & 5 & 7 & 1 & 9 & 2 & 7 & 6 & 7 & 8 & 9 \\
\hline & A & $\mathrm{T}$ & $\mathrm{T}$ & $\mathrm{G}$ & $\mathrm{C}$ & $\mathrm{C}$ & $\mathrm{C}$ & $\mathrm{T}$ & $\mathrm{A}$ & $\mathrm{C}$ & $\mathrm{C}$ & $\mathrm{G}$ & $\mathrm{C}$ & - & A & $\mathrm{T}$ & $\mathrm{G}$ & $\mathrm{T}$ \\
\hline Change of & $\mathrm{C}$ & $\mathrm{G}$ & - & - & - & - & $\mathrm{L}$ & $\mathrm{S}$ & $\mathrm{S}$ & $\mathrm{C}$ & $\mathrm{S}$ & $\mathrm{S}$ & $\mathrm{S}$ & - & $\mathrm{N}$ & $\mathrm{N}$ & $\mathrm{N}$ & $\mathrm{N}$ \\
\hline
\end{tabular}




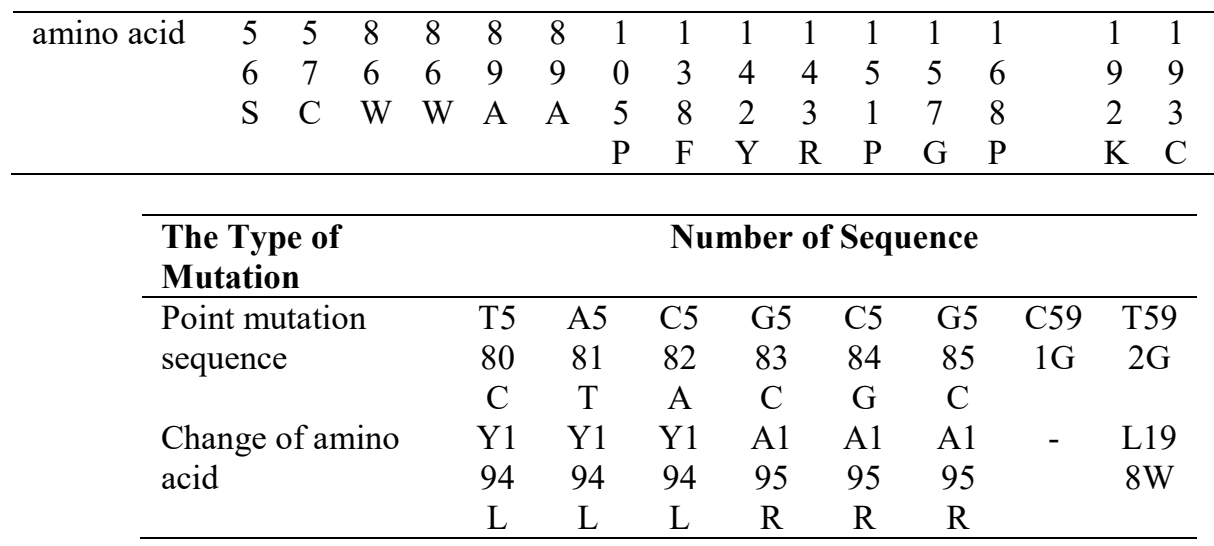

Table 4. Frequency of amino acid $r b c L$ gene on control and orchid infected ORSV isolate $\mathrm{KRB}$

\begin{tabular}{|c|c|c|c|c|c|c|c|c|c|c|c|c|c|c|c|c|c|c|c|c|c|}
\hline \multirow[t]{4}{*}{ Isolate } & \multicolumn{21}{|c|}{ Frequency of Amino Acid (\%) } \\
\hline & $\mathbf{A}$ & $\mathbf{C}$ & $\mathbf{A}$ & $\mathbf{G}$ & $\mathbf{P}$ & $\mathbf{G}$ & $\mathbf{H}$ & $\mathbf{I}$ & $\mathbf{L}$ & $\mathbf{L}$ & $\mathbf{M}$ & $\mathbf{A}$ & $\mathbf{P}$ & $\mathbf{G}$ & $\mathbf{A}$ & $\mathbf{S}$ & $\mathbf{T}$ & $\mathbf{V}$ & $\mathbf{T}$ & $\mathbf{T}$ & $\mathbf{T}$ \\
\hline & 1 & $\mathbf{y}$ & $\mathbf{s}$ & 1 & $\mathbf{h}$ & 1 & $\mathbf{i}$ & 1 & $\mathbf{y}$ & e & $\mathbf{e}$ & $\mathbf{s}$ & $\mathbf{r}$ & 1 & $\mathbf{r}$ & e & $\mathbf{h}$ & $\mathbf{a}$ & $\mathbf{r}$ & $\mathbf{y}$ & $\mathbf{0}$ \\
\hline & $\mathbf{a}$ & $\mathbf{s}$ & $\mathbf{p}$ & $\mathbf{u}$ & e & $\mathbf{y}$ & $\mathbf{s}$ & e & $\mathbf{s}$ & $\mathbf{u}$ & $\mathbf{t}$ & $\mathbf{n}$ & $\mathbf{o}$ & $\mathbf{n}$ & g & $\mathbf{r}$ & $\mathbf{r}$ & 1 & p & $\mathbf{r}$ & $\mathbf{t}$ \\
\hline \multirow{5}{*}{ Control } & & & & & & & & & & & & & & & & 1 & & & & & \\
\hline & 1 & 7 & 2 & 1 & 3 & 6 & 1 & 8 & 2 & & 3 & & 3 & 4 & 8 & 5 & 3 & 3 & 4 & 7 & \\
\hline & , & , & , & , & , & , & , & , & , & 6 , & . & 4, & , & , & , & , & , & , & , & , & 1, \\
\hline & 6 & 6 & 7 & 0 & 2 & 0 & 0 & 7 & 1 & 5 & 2 & 3 & 8 & 3 & 7 & 3 & 8 & 2 & 3 & 6 & 6 \\
\hline & 4 & 5 & 3 & 9 & 8 & 1 & 9 & 4 & 9 & 6 & 8 & 7 & 3 & 7 & 4 & 0 & 3 & 8 & 7 & 5 & 4 \\
\hline \multirow[t]{5}{*}{ KRB } & & & & & & & & & & & & & & & & 1 & & & & & \\
\hline & 1 & 7 & 2 & 1 & 3 & 5 & 1 & 8 & 2 & & 3 & & 5 & 4 & 9 & 3 & 3 & 2 & 5 & 7 & \\
\hline & , & , & , & , & 3 & , & , & 3 & , & 5 , & , & 3 , & 3 & 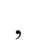 & , & , & , & , & , & 3 & 1, \\
\hline & 6 & 6 & 7 & 0 & 8 & 9 & 0 & 1 & 7 & 9 & 2 & 8 & 4 & 3 & 7 & 0 & 8 & 7 & 4 & 6 & 6 \\
\hline & 3 & 1 & 2 & 9 & 0 & 8 & 9 & 5 & 2 & 8 & 6 & 0 & 3 & 5 & 8 & 4 & 0 & 2 & 3 & 1 & 3 \\
\hline
\end{tabular}

$\mathrm{KRB}$ isolates have undergone mutations and changes in amino acids in the sequence of $\mathrm{CP}$ genes and rbcL genes. This mutation is a process of adaptation and physiological response of the host virus to the natural environment in Indonesia. Some nucleotide mutations that occur are able to cause a change in the amino acid formed in the genome arrangement of chloroplasts DNA. Changes in amino acids will change the function of the genes that are arranged, so that the effectiveness also changes. In this study, increased synthesis of amino acids Phe is related to the synthesis of chloroplasts. Synthesis of the amino acid phenylalanyltRNA on chloroplasts isolated [11]. The presence of the amino acid is related to the formation of chloroplasts and repair damaged as a result of virus infection. [10] also reported had an increased response to the amino acid. In previous studies, virus adaptation to Indonesia's natural environment caused an increase in Gly, Val, and Ala [9].

Most of conserved genes, including the chloroplast gene, have the proffreading mechanism capability. This causes the organism to make corrections and correct errors that occur during the process of replicating the genome. The relatively large genome size of the chloroplast DNA, a slight error (mutation) will not provide any significant effect. This is different for viruses, mutations are a common to happen. This is accordance with the results of the 
sequence analysis, $C P$ gene was obtained most mutation is a deletion, whereas in $r b c L$ gene is substitution. Substitution mutations may affect fewer changes in amino acids than deletions. Deletion of $C P$ gene occurs 7 times, while $r b c L$ gene is 1 time. While the substitution of $C P$ gene occurred 9 times, while $r b c L$ gene was 23 times. The deletion 7 times on $C P$ gene causes changes in 4 amino acids (Asp, Arg, Tyr, and Tre), while substitutions 23 times on $r b c L$ gene only cause changes in 3 amino acids (Leu, Arg, and Trp).

Many mutations that occur in viruses are supported by the ability to adapt to the environment and expand the host range. The hypothesis states that the emergence of a severe type of viral infection in a geographical location and achieving fitness to infect certain types of hosts will cause a loss of the ability of the virus to re-infect its original host. In this study, the presence of host chloroplast DNA mutations is a form of self-adjustment to viral infections leading to fitness due to selection. Mutation rates produce genetic variations in both viruses and hosts. Matthews ${ }^{11}$ the large number of mutations and genetic variations produced increases the probability of evolution faster. The results of this study can be used as basic information to study plant physiological responses to viral infections through molecular identification of chloroplasts.

Research plant-virus relationships on $r b c L$ gene in orchids has never been done before, so information is still limited. Similar studies have been carried out but in hybrid orchids [10]. Studied chloroplasts gene analysis is more commonly reported for phylogenetic studies, data collection on plant species diversity, observing intraspecific variations and knowing the physiological response of plants through host-virus interaction patterns [5]. Similar research still needs to be continued on different types of orchids and sample locations to find out more information about plant-virus relationships in Indonesian orchids.

This study discovered the KRB isolates have undergone mutations and changes in amino acids in the sequence of $C P$ genes and $r b c L$ genes that can be beneficial for plant-virus relationship and as well as data to prevent viral infections on native orchid in Indonesia. This study will help the researchers to uncover the critical areas of Impact of viral infection on damage to chloroplasts based on molecular analysis that many researchers were not able to explore. Thus a new theory on the occurrence of mutation as a process of adaptation and physiological response of the host virus to the natural environment in Indonesia may be arrived.

\section{Conclusion}

Molecular identification of viral RNA and chloroplast DNA in orchids infected with Odontoglossum ringspot virus (ORSV) showed an amplicon measuring $\pm 474 \mathrm{pb}$ and \pm 599 $\mathrm{bp}$. The results of sequence analysis of KRB isolates showed a point mutation and an increase in Ser, Glu, Pro, and Arg amino acids synthesis as a process of adaptation and physiological response of the host virus to the natural environment in Indonesia. 


\section{References}

[1] Cohen, I., Y. Sapir, \& M. Shapira: A Conserved Mechanism Controls Translation of Rubisco Large Subunit in Different Photosynthetic Organisms. Plant Physiol., 141: 10891097. DOI: https://doi.org/10.1104/pp.106.079046 (2006)

[2] Hidayat, T., \& A. Pancoro: Kajian Filogenetika Molekuler dan Peranannya dalam Menyediakan Informasi Dasar untuk Meningkatkan Kualitas Sumber Genetik Anggrek. Jurnal Agro Biogen, 4: 35-40. DOI: http://dx.doi.org/10.21082/jbio.v4n1 (2008)

[3] Inouye, N., \& I.W. Gara: Detection and Identification of Viruses of Orchid in Indonesia. Bull, Res, Inst. Bioresour., 4: 109-118. Available from: https://www.cabi.org/ISC/abstract/19961006876 (1996)

[4] Khentry, Y., A. Paradormuwat, S. Tantiwitat, S. Phansiri, \& N. Thaveechai: Incidence of Cymbidium mosaic virus and Odontoglossum ringspot virus in Dendrobium spp. in Thailand. Crop Protection, 25: 925-932. DOI: 10.1016/j.cropro.2005.12.002 (2006)

[5] Kolondam, B.J., E. Lengkong, J. Polii-Mandang, A. Pinaria, \& S. Runtunuwu: Barcode DNA Berdasarkan Gen $r b c L$ dan matK Anggrek Payus Limondok (Phaius tankervilleae). Jurnal Bioslogos, 2: 55-62. Available from: https://ejournal.unsrat.ac.id/index.php/ bioslogos/article/view/1041 (2012)

[6] Mahfut, \& B.S. Daryono: Deteksi Odontoglossum ringspot virus (ORSV) Terhadap Anggrek Alam di Hutan Wonosadi, Gunung Kidul. Biogenesis, 2: 101-108. DOI: https://doi.org/10.24252/bio.v2i2.475 (2014)

[7] Mahfut, T. Joko, \& B.S. Daryono: Molecular Characterization Molecular of Odontoglossum ringspot virus (ORSV) in Jawa and Bali, Indonesia. Asian Journal of Plant Pathology, 10: 9-14. DOI: 10.3923/ajppaj.2016.9.14 (2016 $\left.{ }^{\mathrm{a}}\right)$

[8] Mahfut, B.S. Daryono, T. Joko, \& S. Somowiyarjo: Survei Odontoglossum ringspot virus (ORSV) yang Menginfeksi Anggrek Alam Tropis di Indonesia. Jurnal Perlindungan Tanaman Indonesia, 20: 1-6. DOI: https://doi.org/10.22146/jpti.16617 (2016 ${ }^{\text {b }}$ )

[9] Mahfut, B.S. Daryono, \& S. Somowiyarjo: Detection of Odontoglossum ringspot virus on Native Orchids Collection of Botanical Gardens in Indonesia. Jurnal Fitopatologi Indonesia, 13: 1-8. DOI: http://dx.doi.org/10.14692/jfi.13.1.1 (2017 $)$

[10] Mahfut, B.S. Daryono, \& S. Somowiyarjo: Identifikasi Molekuler DNA Kloroplas Pada Anggrek Terinfeksi Odontoglossum ringspot virus (ORSV) di Magelang, Jawa Tengah. In: Seminar Nasional Pengendalian Penyakit Pada Tanaman Pertanian Ramah Lingkungan II. Universitas Gadjah Mada, 27 Agustus 2016, Perhimpunan Fitopatologi Indonesia Komisariat Daerah Yogyakarta, Solo, dan Semarang, pp: 354-360. Available from: https://www.researchgate.net/publication/322886373 Identifikasi_Molekuler_DNA Kloroplas_Pada_Anggrek_Terinfeksi_Odontoglossum_ringspot_virus_ORSV_di_Magela ng_Jawa_Tengah $\left(2017^{\mathrm{b}}\right)$

[11] Matthews, R.E.F.: Plant Fundamental of Plant Virology. California. Academy Press Inc., pp: 1. Available from: https://www.sciencedirect.com/book/9780124805583/fundamentals-of-plantvirology (1992)

[12] Pataky, N.R.: Common Virus Diseases of Orchids: Report on Plant disease. Department of Sciences, University of Illinois at Urbana-Champaign. RPD No. 164, pp: 1-4. Available from: https://ipm.illinois.edu/diseases/rpds/614.pdf (1990)

[13] Reger, B.J., S.A. Fairfield, J.L. Epler, \& W.E. Barnett: Identification and origin of some chloroplast aminoacyl-tRNA synthetases and tRNAs. Proc. Natl. Acad. Sci., 67:1207-13. DOI: https://doi.org/10.1073/pnas.67.3.1207 (1970) 
[14] Sherpa, A.R., V. Hallan , \& A.A. Zaidi: Cloning and sequencing of coat protein gene of an Indian Odontoglossum ringspot isolate. Acta Virol., 48: 267-269. DOI: https://doi.org/10.1071/ap05094 (2004)

[15] Taiz, L. and E. Zeiger: Plant Physiology. The Benyamin/Cummings Publishing Company, Inc., California, 559 p (1991)

[16] Zettler, F.W., N.J. Ko, Wisler, G.C., Elliot, M.S., \& S.M. Wong: Viruses of orchids and their control. Plant Dis., 74: 621-626. DOI: https://doi.org/10.1094/PD-74-0621 (1990) 